ROCZNIKI HUMANISTYCZNE

Tom LXIX, zeszyt $6-2021$

DOI: https://doi.org/10.18290/rh21696-7

KINGA LIS

\title{
BEHIND THE EARLY MODERN ENGLISH TRANSLATION OF THE LAWS OF OLERON: DETERMINING THE UNDERLYING FRENCH TEXT*
}

\section{INTRODUCTION}

In the first half of the 16th century an English translation of the Laws of Oléron - a code of sorts, regulating relationships, on board a ship and in ports, between the agents involved in transporting goods, mainly wine, between certain geographical locations - was completed. The code itself was a much older creation, known in England from at least the 14th century in its French-language versions. Accounts concerning the translation which can be gathered from the relevant sources are divergent in multiple respects, such as the number of renditions, the authorship, date and place of creation, the relationship between the texts/renditions, the content and the source text(s). It would be well beyond the scope of this paper to investigate all of these issues. Therefore, it is exclusively the source text that is of primary interest here, with the remaining points being only briefly mentioned. In other words, the objective of this paper is to determine which of the Middle French texts analysed is the probable source text of the English rendition.

Dr KINGA LIS - adiunkt w Katedrze Historii Języka Angielskiego i Translatoryki Katolickiego Uniwersytetu Lubelskiego Jana Pawła II; adres do korespondencji: Katolicki Uniwersytet Lubelski Jana Pawła II, Instytut Językoznawstwa, Al. Racławickie 14, 20-950 Lublin; e-mail: kinga.lis@kul.pl. ORCID: http://orcid.org/0000-0002-7888-098X.

${ }^{*}$ I would like to thank Professor Magdalena Charzyńska-Wójcik for all her comments and suggestions with respect to the earlier drafts of the paper. I would also like to express my gratitude to the two anonymous reviewers whose comments and remarks were invaluable. 
The paper begins by introducing the relevant text - the code-and its Early Modern English (eMnE) translation in Section 2, and gives a brief account of the divergent opinions concerning its source text in Section 3.1. Section 3.2 analyses various aspects of the French texts on which the eMnE rendition is supposedly based in an attempt to establish which of them is its actual source. The findings are summarised in Section 4.

\section{THE LAWS OF THE OLÉRON- \\ THE ORIGIN OF THE TEXT AND THE ENGLISH-LANGUAGE VERSION}

The origins of the Laws of Oléron are obscure and various accounts of their creation have been proposed. ${ }^{1}$ The earliest extant copies of the text are in AngloNorman (AN) and date back to the early 14 th century. ${ }^{2}$ It is, however, accepted that the original text was written down in the late 13th century (Frankot 159) and adopted by the rulers of Aquitaine (Studer xxxiv). Even the name of the text comes in different forms, such as Judgements of Oléron, Laws of Oléron, Rolls of Oléron and Statutes of Oléron, whose only common denominator is the name of the island Oléron, which lies off the western coast of France. Whether the text originated there is, however, disputed.

Despite such an early compilation date and the fact that the text was known in England from the beginning of the 14th century (Twiss lvii-lviii), it was only in the 16th century that a translation of the text into (Early Modern) English was attempted.

Pardessus considers the rendition to be the work of "W. Copland," who translated Pierre Garcie's ${ }^{3}$ text and printed it for the first time (310-311). As to the dating, Pardessus proposes a post-1542 date, since it was only in 1542 that-according to his knowledge-Garcie's work was published (311).

According to Twiss (lxxii), not one, but two renditions were completed in the early 16th century. One of them translated the text contained in Le grant routier

\footnotetext{
${ }^{1}$ For more information on the topic, see Pardessus (283).

${ }^{2}$ These are contained in Liber Memorandorum (COL/CS/01/003) and Liber Horn (COL/ $\mathrm{CS} / 01 / 002)$, kept in the London Metropolitan Archives. The AN copies of the text are not, however, the object of investigation here, as no direct line of descent between them and the texts analysed here can be postulated.

${ }^{3}$ Pierre Garcie dit Ferrande (ca. 1440-1502) is considered to be the father of marine cartography, being the author of a rutter (1483-1484), a reference work for maritime navigation. Its manuscript version is lost (Bochaca and Moal 89), but a printed version of the work (Le Grand Routier) gained widespread popularity and became a standard book of reference for mariners.
} 
compiled by Garcie, consisting of 46 articles $^{4}$ (Twiss lxxii), and was published in London in 1528 by Robert Copland, its translator (Twiss lxxii). The other rendition translated an early version of the text as was known in Brittany (Twiss 1xxii), and whose close copy can be found in Le grand costumier de Normandie, published in Rouen by Nicholas le Roux in 1539 (Twiss 89). According to Twiss (lxxii-lxxiii), its English rendition was published by Thomas Petyt in London in 1536 in the book called The Rutter of the See. ${ }^{5}$

Studer, trying to reconcile the two views, states that "[a]lready in the sixteenth century we find English versions based upon some Norman version, e.g., Thomas Petyt's Rutter of the Sea of 1536, or especially upon the texts of Garcie and Cleirac, ${ }^{6}$ for example, Copland's Rutter of the Sea of 1528 " (xli).

Thus, no reference to Copland's given name is made-probably in an attempt to avoid discussing the divergence in sources. What is, however, worth noting is that the title of the earlier work is also mentioned, and is exactly the same as the one given to Petyt's publication.

It would thus seem that one is indeed dealing with at least two independent 16th-century translations, based on different source texts, varying in length and given the same title. The situation changes dramatically when, instead of consulting the sources concerning the Laws of Oléron, one turns to the very books in which they appeared, both carrying the title of The Rutter of the Sea. There are at least eight sources (Senior, Waters (Rutters 31), Blayney (401), de Maisonneuve (41), the Dictionnaire des auteurs anglais (n.d.), English Short Title Catalogue (ESTC) and Department of Vendée's official website) where the information is provided that The Rutter of the Sea, first published in London in 1528 and translated into English from French by Robert Copland, went through multiple editions, one of them being the 1536 Thomas Petyt edition. Four of the sources, i.e. Waters (Rutters 31), de Maisonneuve (41), the Dictionnaire des auteurs anglais (n.d.), ESTC, provide lists of these editions, but these, however, diverge both in terms of the number of editions and in their publication dates and attributions. An

\footnotetext{
${ }^{4}$ The term article will be used in the body of this paper with this meaning in mind-a separate 'clause' or 'provision' of the code.

${ }^{5}$ A rutter, adopted from French routier, was "a pilot's notebook," "an early book of sailing directions" (Dictionary of Nautical Words and Terms).

${ }^{6}$ Étienne Cleirac (1583-1657) was a provincial lawyer who specialised in maritime law. He is the author of the Us et coustumes de la mer, which "first appeared in Bordeaux in 1647: a vernacular publication that assembled, translated, and commented on legal norms about maritime trade issued in western and northern Europe from the twelfth century to the then present" (Trivellato 194). Among other texts it contained a translation of the Laws of Oléron, which in his edition counted 47 articles (Trivellato 215).
} 
attempt at clearing up the confusion was made in Lis. At this point, it suffices to say that all the sources agree as to the two texts in question, i.e. Robert Copland's and Thomas Petyt's editions, even though not much is left of the former, being but copies of the same document.

The question that still remains unanswered is that concerning the source text of the rendition, and more specifically of the Laws of Oléron contained in the book. As mentioned above, various source texts were postulated with respect to Petyt's and Copland's texts of the code. And yet, as the two have proved to be simply different editions of the same text, the issue of the underlying French original becomes even more intriguing.

\section{THE UNDERLYING FRENCH TEXT}

2.1 Various accounts found in the relevant literature

Some information concerning the origin of the complete eMnE translation known as The Rutter of the Sea is provided in the very prologue to the text, which is cited here after Petyt's 1536 edition (fol. a.ii v.-fol. a.iii v).

C All this dyscretly pondred by a sad / ingenyous and cyrcumspecte maryner of the cyte of London beynge in y towne of Bourdews bought a prety boke enprynted in $\stackrel{e}{y}$ Frenche language called the Rutter of the see [...] The whiche boke he instaū=ted me to translate ito englysshe. whi=che ouersene / me thought veray dyf=ficyle to me / not knowynge the termes of maryners / and names of the costes and hauens / for I came neuer on the see nor by no coste therof. But folow=ynge my copye by the aduyse and ouersyght of certayne cōnynge men of that scyence whiche bolded and informed me $\overline{1}$ many doubtes / I dyd vndertake it doynge my dylygence [...].

Thus, according to the prologue, a London mariner purchased a copy of a French version of the text in Bordeaux and, having brought it back to England, he ordered a translation of the text. The endeavour was entrusted to the author of the prologue, who, not himself acquainted with the marine world, obtained help and advice from people with hands-on knowledge of the subject matter. Having presented the story behind the rendition, the translator asks the future reader to amend the text wherever the need may arise, for which effort they will "be hyghly rewarded of almyghty god, which is cheyf may=ster and lodesman of 7 to euery streme and cost" (fol. a.iii v). The name of the translator/author of the prologue is not given in the 1536 edition, but the remaining editions to which I gained access, i.e. 1557, 1560(?), 1567(?), 1573(?), state that it is Robert Copland. 
It is, therefore, clear that The Rutter of the Sea was translated from French in or on a date preceding 1528, when the first edition of the book was published. When one looks at the publication globally, there are a few possibilities as regards the potential source text but they all seem to have one common denominator, i.e. Pierre Garcie:

1. Garcie's work, as postulated in Pardessus (310-311) for W. Copland's translation;

2. Garcie's Le grant routier, as stated in Twiss (lxxii) for Robert Copland's edition;

3. Garcie's and Cleirac's version, as Studer (xli) indicated for Copland's Rutter of the Sea;

4. Garcie's Le grand routier, pillotage et encrage de mer, as given in the British Library records for the 1550-1560 editions of The Rutter of the Sea.

One should not, however, lose track of the fact that both Twiss (vol. I) and Studer, most probably on Twiss's authority, also mentioned a different source text for the 1536 edition of the Laws of Oléron, but not for the whole book:

5. "a version of the Judgments, which was current in the Duchy of Brittany and was nearly identical with the version printed in the Grand Costumier de Normandie at Rouen, by Nicholas le Roux, 1539" (Twiss 89)-discussed in Twiss (vol. I) with respect to Petyt's edition and referred to as "some Norman version" in Studer (xli).

Those accounts would be less problematic if Robert Copland's and Thomas Petyt's texts had not been editions of the same book translated from French, and had not included the same version of the Laws of Oléron. In light of this, however, the question seems quite convoluted. In general, two main alternative ideas as to the source text can be distinguished: it was either Garcie's work, orif one is to pursue Twiss's (vol. I) insistence on a different source text for Petyt's edition - a version of the laws in use in Brittany.

When one turns to the literature dealing with the topic of The Rutter of the Sea and Garcie's publication, the issue appears to become even more complex, as yet another text enters the equation, albeit not in all researchers' accounts.

Sheppard seems to agree with Garcie's authorship, but would see the eMnE translation as an abridged version of Le grant routier (18-19). According to him, Garcie's work "[i]n an abridged form [...] appeared anonymously in four English editions as The Rutter of the Sea, translated by Robert Copland" (Sheppard 19).

Waters (Navigation 12-13 and Rutters 4) is of the same opinion as regards the authorship of the source text. However, rather than speaking of the English translation as an abridged version of the French text, he refers to a different 
French text-shorter than Le grant routier-that served as the basis for the rendition (Waters, Rutters 4). The work in question is Le routier de la mer, which was the very first rutter to have been printed in north-west Europe. ${ }^{7}$ It was published in Rouen between 1502 and $1510^{8}$ (Waters, Navigation 12) and most probably it is this 1502 edition that was brought to England by the mariner mentioned in the prologue (Waters, Navigation 13). Interestingly, the author of the 1502 text is not named in the publication but, as Waters (Rutters 4) argues, "it can be confidently ascribed to Pierre Garcie after comparison of its text with that of the much larger Le grant routier in which the authorship is attributed in several places to Pierre Garcie."

The same opinion is presented in de Maisonneuve's work, where the author states that (i) the manuscript version of the text originally created by Garcie, (ii) Le routier de la mer (1502) and (iii) Le grant routier (1520) all have the same author (de Maisonneuve 29). Both Waters (Rutters) and de Maisonneuve compared the two French texts (Le routier de la mer and Le grant routier), and de Maisonneuve went even so far as to add to the comparison a manuscript version of Garcie's original (pre-1490) text from a 1522 manuscript kept in the Bibliothèque nationale de France (Cest le routtier), and they both unhesitatingly consider the texts to bear an undeniable resemblance.

The Bibliothèque nationale de France is not as adamant in claiming Garcie's authorship for Le routier de la mer, whose complete title is Le Routier de la mer jusques au fleuve de Jourdain. The author's name is not given in the publication; ${ }^{9}$ instead the library informs its readers that Garcie is the presumed author. The text was printed in Rouen by Jacques le Forestier (?-1512), most probably between 1502 and 1509, and is the first published French work on hydrography (Bibliothèque nationale de France).

A similar stance is taken in Une histoire de l'hydrographie française published online by the Amhydro society, where one can read:

Le plus ancien hydrographe connu en France est Pierre Garcie, dit Ferrande, un maître de cabotage vendéen d'origine portugaise ou espagnole. Il rédigea vers 1483 un routier publie en 1502 sous une forme abrégée, Le routier de la mer : jusques au

\footnotetext{
${ }^{7}$ The same information is given in Fumerton (110).

${ }^{8}$ From now on, unless necessary, I will give the 1502 date with respect to the text, for the sake of clarity.

${ }^{9}$ The catalogue reference for the publication is Res-Z-2747 (Bibliothèque nationale de France, département Réserve des livres rares). The book is available in two digital versions on Gallica, of which one is of much higher quality, but lacks the image of one of the pages.
} 
fleuve de Jourdain avant d'être publié en version intégrale à partir de 1520 et jusqu'en 1648 sous le titre Le grant Routtier, Pillotage et Encrage de Mer. ${ }^{10}$

(Une histoire de l'hydrographie française Chapter 3, p. 1)

The investigation into Le grant routier conducted in Bochaca and Moal's publication presents the issue in an altogether different light. The study openly rejects the idea that the two printed French rutters share authorship, stating with respect to Le routier de la mer that:

Auguste Pawlowski et ceux qui, après lui, s'intéressèrent au Routier de la mer jusques au flueve de Jourdain y ont vu un «petit routier», version abrégée ou incomplète du Grand Routier de Pierre Garcie. Aucun élément de critique interne et externe de ce texte ne permet d'en attribuer la paternité à Pierre Garcie. ${ }^{11}$

(Bochaca and Moal 65)

The two standpoints concerning the authorship of Le routier de la mer are irreconcilable, but Bochaca and Moal do concur with the idea that the eMnE translation was rendered from the text in question, and not from Le grant routier (65). Since my primary aim is to establish the source with which to juxtapose the English text, the question of the authorship of Le routier de la mer and its relationship with the bigger work - unequivocally attributed to Pierre Garcie-falls beyond the scope of this study. Therefore, from now on I will limit the discussion to the Laws of Oléron as contained in the three potential source texts, i.e.

1. Le grant routier authored by Pierre Garcie; ${ }^{12}$

2. Le routier de la mer of uncertain authorship; ${ }^{13}$

3. a version of the laws as known in Brittany, similar to the copy printed in the 1539 Grand costumier de Normandie, compiled by Nicholas le Roux.

10 "The first known French hydrographer is Pierre Garcie dit Ferrande, a shipmaster of Vendée, of Portugal or Spanish origin. In 1483 he compiled a rutter, which was published in an abridged form in 1502 (Le routier de la mer: jusques au fleuve de Jourdain), before being published in its entirety as Le grant Routtier, Pillotage et Encrage de Mer in the years 1520-1648." (translation mine)

11 "Auguste Pawlowski and those after him who were interested in Routier de la mer jusques au flueve de Jourdain saw in it a "small rutter», an abridged or incomplete version of Pierre Garcie's Grand Routier. No element of internal or external criticism of this text allows one to attribute it to Pierre Garcie's authorship." (translation mine)

${ }^{12}$ Waters (Rutters 28-29) lists 30 editions of the work, and de Maisonneuve 27 (2015, 30-41).

${ }^{13}$ Only one extant copy of the text is known. 
2.2 Analysis of the potential source texts

\subsubsection{The texts compared here}

In the light of the incongruent accounts pertaining to the texts, the only viable way of establishing the source text of the eMnE rendition involves an examination of the three documents listed above. For this purpose, I have consulted the Laws of Oléron from three early editions of Le grant routier, the only available copy of Le routier de la mer and the Grand Costumier de Normandie:

1. the first French edition of Le grant routtier et pillotage et enseignement $[. .$.$] - printed by Enguilbert de Marnef in 1520$ in Poitiers (Bibliothèque Pierre-Moinot in Niort, RES-161E);

2. the 1525 edition of Le grant routier et pilotage et enseignement [...]printed by Jehan Burges le Jeune (Bibliothèque nationale de France, département Réserve des livres rares, SMITH LESOUEF R-198);

3. two copies of the 1531 edition of Le grant routier et pilotage et enseignement [...] — printed by Jehan Burges le Jeune (Bibliothèque nationale de France, (i) département Arsenal, 4-S-3426, and (ii) département Réserve des livres rares, RESP-V-128);

4. Le routier de la mer iusques au fleune de Jourdain-printed in 1502 in Rouen by Jacques le Forestier (Bibliothèque nationale de France, département Réserve des livres rares, RES-Z-2747);

5. Le grand coustumier du pays (et) duche de Normendie [...]—-printed by Nicolas le Roux in 1539 in Rouen (Bibliothèque nationale de France, département Réserve des livres rares, RES-F-627).

\subsubsection{The different copies of Le grant routier}

Despite minor divergences between the two 1531 copies of Le grant routier as regards their front page, their contents are exactly the same, even as far as typographical details are concerned, for which reason they will be treated here jointly. The correspondences between the 1520, 1525 and 1531 editions of Le grant routier are presented in Table 1 below. The articles are not numbered in the relevant texts, and I preserve the numbering imposed in Englebert's edition. It should be noted that the total number of articles in Garcie's text equals 46, as indicated by Twiss (lxxii), where he discussed Le grant routier as the source text for Robert Copland's translation. 
Table 1. The division and presentation of articles

in Le grant routier 1520, 1525 and 1531 editions

\begin{tabular}{|c|c|c|c|c|c|}
\hline $\begin{array}{c}\text { Article } \\
\text { and folio } n^{0} \\
\text { in the } 1520 \\
\text { edition }\end{array}$ & $\begin{array}{c}\text { Article } \\
\text { and folio } n^{0} \\
\text { in the } 1525 \\
\text { edition }\end{array}$ & $\begin{array}{c}\text { Article } \\
\text { and folio } n^{0} \\
\text { in the } 1531 \\
\text { edition(s) }\end{array}$ & $\begin{array}{c}\text { Article } \\
\text { and folio } \mathrm{n}^{0} \\
\text { in the } 1520 \\
\text { edition }\end{array}$ & $\begin{array}{c}\text { Article } \\
\text { and folio } n^{0} \\
\text { in the } 1525 \\
\text { edition }\end{array}$ & $\begin{array}{c}\text { Article } \\
\text { and folio } n^{0} \\
\text { in the } 1531 \\
\text { edition(s) }\end{array}$ \\
\hline 1 (f. 86v) & 1 (f. 68r) & 1 (f. R.vii) & 24 (f. 91r) & 24 (f. 71v) & 24 (f. S.vi) \\
\hline 2 (f. 86v) & 2 (f. $68 \mathrm{v})$ & 2 (f. R.viii) & 25 (ff. 91r-v) & 25 (ff. $71 v-72 r$ ) & 25 (ff. S.vi-vii) \\
\hline 3 (ff. $86 v-87 r$ ) & $3($ (f. $68 v)$ & 3 (f. R.viii) & 26 (f. 91v) & 26 (f. 72r) & 26 (f. S.vii) \\
\hline 4 (f. 87 r) & 4 (ff. $68 v-69 r)$ & 4 (ff. R.viii-S.i) & 27 (ff. 91v-92r) & 27 (f. 72r) & 27 (f. S.vii) \\
\hline 5 (ff. $87 \mathrm{r}-\mathrm{v}$ ) & 5 (f. 69r) & 5 (f. S.i) & 28 (f. 92r) & 28 (f. $72 v)$ & 28 (f. S.viii) \\
\hline $6(\mathrm{f} .87 \mathrm{v})$ & 6 (f. 69r) & 6 (f. S.i) & $\begin{array}{l}29 \text { (ff. 92v-93r) } \\
\text { (appears to } \\
\text { consist of two } \\
\text { articles) }\end{array}$ & $\begin{array}{l}29 \text { (ff. } 72 \mathrm{v}-73 \mathrm{r}) \\
\text { (appears to } \\
\text { consist of two } \\
\text { articles) }\end{array}$ & $\begin{array}{l}29 \text { (ff. S.viii-T.i) } \\
\text { (appears to } \\
\text { consist of two } \\
\text { articles) }\end{array}$ \\
\hline 7 (f. $87 v)$ & 7 (f. 69r) & 7 (f. S.i) & 30 (f. 93r) & 30 (f. 73 r) & 30 (f. T.i) \\
\hline 8 (f. 88 r) & 8 (ff. 69r-v) & 8 (ff. S.i-ii) & 31 (f. 93r) & 31 (f. 73r) & 31 (f. T.i) \\
\hline 9 (ff. 88r-v) & $9($ f. $69 \mathrm{v})$ & 9 (f. S.ii) & 32 (ff. 93r-v) & 32 (f. 73r) & 32 (f. T.i) \\
\hline 10 (f. $88 \mathrm{v}$ ) & 10 (ff. $69 \mathrm{v}-70 \mathrm{r})$ & 10 (ff. S.ii-iii) & 33 (f. 93v) & 33 (f. 73r) & 33 (f. T.i) \\
\hline 11 (ff. 88v-89r) & 11 (f. 70r) & 11 (f. S.iii) & 34 (f. 93v) & 34 (ff. 73r-v) & $\begin{array}{l}34 \text { (f. T.i and the } \\
\text { last sentence } \\
\text { moved to f. T.x) }\end{array}$ \\
\hline 12 (f. 89r) & 12 (f. 70r) & 12 (f. S.iii) & 35 (f. 93v) & 35 (f. 73v) & 35 (f. T.x) \\
\hline 13 (f. 89r) & 13 (f. 70r) & 13 (f. S.iii) & 36 (f. 93v) & 36 (f. $73 v$ ) & 36 (f. T.x) \\
\hline 14 (ff. 89r-v) & 14 (ff. f. 70r-v) & 14 (ff. S.iii-iv) & 37 (f. 94r) & 37 (f. 73v) & 37 (f. T.x) \\
\hline 15 (f. 89v) & 15 (f. 70v) & 15 (f. S.iv) & 38 (f. 94r) & 38 (f. $73 v$ ) & 38 (f. T.x) \\
\hline 16 (ff. 89v-90r) & 16 (f. 70v) & 16 (f. S.iv) & 39 (f. 94r) & 39 (f. $73 v$ ) & 39 (f. T.x) \\
\hline 17 (f. 90r) & 17 (ff. 70v-71r) & 17 (ff. S.iv-v) & 40 (f. 94r) & 40 (f. $73 v$ ) & 40 (f. T.x) \\
\hline 18 (f. 90r) & 18 (f. 71r) & 18 (f. S.v) & 41 (f. 94r) & 41 (ff. $73 v-74 r$ ) & 41 (ff. T.x-xi) \\
\hline 19 (f. 90r) & 19 (f. $71 \mathrm{r})$ & 19 (f. S.v) & 42 (f. $94 r$ ) & 42 (f. $74 r$ ) & 42 (f. T.xi) \\
\hline 20 (f. $90 \mathrm{v})$ & 20 (f. 71r) & 20 (f. S.v) & 43 (f. 94v) & 43 (f. 74r) & 43 (f. T.xi) \\
\hline 21 (f. 90v) & 21 (f. 71r) & 21 (f. S.v) & 44 (f. 94v) & 44 (f. $74 r)$ & 44 (f. T.xi) \\
\hline 22 (f. $90 \mathrm{v})$ & 22 (ff. 71r-v) & 22 (ff. S.v-vi) & 45 (ff. $94 v-95 r$ ) & 45 (f. $74 \mathrm{r})$ & 45 (f. T.xi) \\
\hline 23 (f. 91r) & $23($ f. $71 v)$ & 23 (f. S.vi) & 46 (f. $95 r$ ) & 46 (f. $74 v)$ & 46 (f. T.iv) \\
\hline
\end{tabular}


The three editions differ slightly between each other as far as orthography, punctuation and, occasionally, lexical choices are concerned, e.g.:

- where in Article 26 the 1520 edition reads "le seigneur du lieu ne doibt empescher la saluation du bris et mar=chandie" (f. 91v), the 1525 text has "le seigneur du lieu ne doit empescher la saluacion de la marchan=dise" (f. 72r), and that of the 1531 edition "le seigneur du lieu ne doit empescher la saluation de la marchan $=$ dise" (f. S.vii);

- where in Article 38 the 1520 edition reads "Item esठ fraict3" (f. 94r), and the 1525 edition "Item esditz fraitz" (f. 73v), the 1531 text has "Et se les dit3 frait3" (f. U.ii);

- where in Article 39 the 1520 edition reads "Item si dauenture" (f. 94r), and the 1525 edition "Item se dauenture" (f. 73v), the 1531 text has "Sy dauenture" (f. U.ii).

However, no major textual divergences have been observed. The only exceptions are misplacements in the 1531 edition, where a rupture occurs at Article 34, which is thus divided between folios T.i and T.x, with Articles 35-45 following, and Article 46 being placed at folio T.iv.

\subsubsection{Le routier de la mer and Le grand coustumier}

Another potential source text for the eMnE translation is Le routier de la mer, which may or may not have been authored by Pierre Garcie. The text of the Laws of Oléron can be found at folios $20 \mathrm{v}-29 \mathrm{v}$ and consists of 26 unnumbered articles. Beneath the text the following statement can be found:

Tesmoing le seel de lisle dausleron esta=bli es cōtract3 de la dicte isle le iour du mardi ā̄s la feste sainct Andre. Lan Mil.cc.lxvi.

This statement corresponds perfectly to the statement ending the 1536 edition of the eMnE rutter as printed by Thomas Petyt:

Wytnes the seale of the yle of Aule=ron / establysshed by the contrac $=$ tes of the sayd yle / y tuesday after the feest of saynte Andrewe[.] The yere of our lorde. M.CC.lxvi.

Furthermore, the introduction to the text is remarkably similar:

Le routier de la mer (1502): Cy commencent les iugemēs de la mer des nefz / des maistres / des mariniers / et aussi des marchans et de tout leur estre.

The Rutter of the Sea (1536): Here begynneth the iudgementes of the see, of shyppes / of maysters / of maryners / of marchaūtes / and of all theyr doynges. 
Finally, according to Twiss (89), one should look at the version of the Laws of Oléron, which was current in Brittany to find the original source text. One text that bears a remarkable resemblance to such version of the laws - as stated in Twiss (89) - is to be found in the 1539 Grand costumier de Normandie compiled by Nicholas le Roux. The text of the Laws of Oléron can be found at folios 1xi.v-lxiii.r of the custumal and is introduced thus:

C Cy commencent les iugemens de la mer / des nefz des maistres / des mariniers et aussi des marchans / 7 de tout leur estre.

At the end of the text one can read:

C Tesmoing le seel de lisle dausleron establi es con=tract3 de ladicte ilse le iour du mardi aprez la feste saict Andre. Lan Mil.cc.lxvj.

Furthermore, this text also contains only 26 articles and the similarities do not stop here. However, before conducting a comparison of these two texts, I present the order of the articles of the Laws of Oléron as contained in Le grant routier, Le routier de la mer and Le grand coustumier.

Table 2. Articles in Le routier de la mer (1502), Le grant routier (1520-1531) and Le grand coustumier (1539)

\begin{tabular}{|c|c|c|}
\hline $\begin{array}{c}\text { Le routier de la mer } \\
(\mathbf{1 5 0 2})\end{array}$ & $\begin{array}{c}\text { Le grant routier } \\
\mathbf{( 1 5 2 0 - 3 1 )}\end{array}$ & $\begin{array}{c}\text { Le grand coustumier } \\
\mathbf{( 1 5 3 9 )}\end{array}$ \\
\hline 1 & 1 & 1 \\
\hline 2 & 2 & 3 \\
\hline 3 & 3 & 4 \\
\hline 4 & 4 & 5 \\
\hline 5 & 5 & 6 \\
\hline 6 & 6 & 7 \\
\hline 7 & 7 & 8 \\
\hline 8 & 8 & 9 \\
\hline 9 & 9 & 10 \\
\hline 10 & 10 & 11 \\
\hline 11 & 11 & 12 \\
\hline 12 & 12 & $\mathbf{1 3}$ \\
\hline $\mathbf{1 3}$ & - & \\
\hline
\end{tabular}




\begin{tabular}{|c|c|c|}
\hline 14 & 13 & 14 \\
\hline 15 & 14 & 15 \\
\hline 16 & 15 & 16 \\
\hline 17 & 16 & 17 \\
\hline 18 & 17 & 18 \\
\hline 19 & 18 & 19 \\
\hline 20 & 19 & 20 \\
\hline 21 & 20 & 21 \\
\hline 22 & 21 & 22 \\
\hline 23 & 22 & 23 \\
\hline 24 & 23 & 24 \\
\hline 25 & 24 & 25 \\
\hline 26 & 25 & 26 \\
\hline- & 26 & - \\
\hline- & 27 & - \\
\hline- & 28 & - \\
\hline- & 29 & - \\
\hline- & 30 & - \\
\hline- & 31 & - \\
\hline- & 32 & - \\
\hline- & 33 & - \\
\hline- & 34 & - \\
\hline- & 35 & - \\
\hline- & 36 & - \\
\hline- & 37 & - \\
\hline- & 38 & - \\
\hline- & 39 & - \\
\hline- & 40 & - \\
\hline- & 41 & - \\
\hline- & 42 & - \\
\hline- & 43 & - \\
\hline- & 44 & - \\
\hline- & 45 & - \\
\hline- & 46 & - \\
\hline
\end{tabular}


As can be observed in Table 2, it is not only the absence of Articles 27-46 that distinguishes Le routier de la mer and Le grand coustumier texts from Le grant routier. Article 13-as given in the two other texts - is altogether absent from $L e$ grant routier.

\subsubsection{Textual comparison of Le routier de la mer, Le grand coustumier} and Le grant routier

As regards the contents of the articles - and it needs to be emphasised that the present analysis is limited to the Laws of Oléron text - and their phrasing, one needs to admit that the similarities between the three text are remarkable, and on reading them one fully comprehends why researchers would postulate that $L e$ routier de la mer can be perceived as an earlier version of Le grant routier and associate, although not all of them do so, its authorship with the author of the latter, i.e. Pierre Garcie. Regardless of whether Garcie is the author of both works, the similarities between them are undeniable.

Differences, however, are also evident. Le grant routier systematises the text by introducing each and every article, with the exception of the first one, by the word item in the 1520 and 1525 editions, and in the 1531 edition only the majority of them. Geographical locations used in the texts are also different. For instance, where Le routier de la mer and Le grand coustumier reference Bordeaux in Articles 4, 11 and 21, Le grant routier mentions La Rochelle in Article 4, Brest in Article 11, and in Article 21 Rouen is employed instead. Furthermore, lexical additions to the text are clearly visible. To provide an illustration of such changes, a part of Article 25 from Le grant routier (1) and the corresponding text from Article 26 in the other two texts (Le routier de la mer and Le grand costumier de Normandie) are quoted below (2-3). Additionally, the eMnE text is provided in (4):

1. Le grant routier (1525 edition): C Item deux nauires vesseaulx ou pinasses sont cōpaignōs pour aller pescher es retz cōme maqueraulx / harēç 7 raies. Du biē mettre les cor=des cōme es parties dolonne / de saint gille sur vie et ailleurs. Et doit lun desð̆ vesseaulx mettre autāt dengyns cōme lautre. Et ainsy seront moytie par moytie en la gaigne par cōuenāce saicte entre eulx. [...] Il est ainsy $\bar{q}$ les amys de celuy qui est mort demāđèt auoir partie en la gaigne q̉ls ont faicte tant en engyns / harenc3 / maquereaulx ou autres poissons et vessel. ${ }^{14}$

2. Le routier de la mer (1502): Deux vaisseaulx sont compaignōs pour aller es harencz ou es maquereaulx / et doi=uent mettre autant dengins lun comme lautre. agre sont de partir la gaigne par moitie entre eulx. [...] Il est ainsi que les a=mis

\footnotetext{
${ }^{14}$ The fragments set in bold are additions with respect to the other two texts.
} 
diceluy q̀ est mort leur demādēt a auoir partie du gaing quilz̧ ont fait tāt es engins que es harencz et au vaissel.

3. Le grand coustumier (1539): C Deux vaisseaulx sont compaignons pour aller es harenç ou aux macquereaulx 7 doibuēt mettre autant dengins lun cōme lautre agre sōt de partir la gaigne p moytie entre eulx. [...] Il est ainsi que les amis diceluy qui est mort leur demandent a auoir partie du gaing quilz ont faict tant aux engins que es harencz et au vaissel.

4. The rutter of the see (1536): Two vesselles be felowes to take Herynges or makerelles / they ought to lay as many gyn̄s one as another / 7 they be agreed to part y gayne by halfe betwene the / and yf it chaunce $\mathrm{y}^{\mathrm{t}}[\ldots]$ frēdes of hym $\mathrm{y}^{\mathrm{t}}$ is deed asketh parte of y gayne $\mathrm{y}^{\mathrm{t}}$ thei haue made / of y gynnes / heryng / 7 vessell. I do not think that any other arguments are needed to show the undeniable similarities between all the documents and the fact that, even so, the texts presented in Le routier de la mer and Le grand costumier de Normandie are much closer to the eMnE translation (4) than Le grant routier's text (1). Therefore, it is clear that theories pertaining to the texts of Le routier de la mer and Le grand costumier de Normandie are correct in pointing to the version of the Laws of Oléron similar to those in the two publications as the source text for the eMnE translation. As regards the hypothesis concerning Le grant routier constituting the basis for the rendition, it is easy to see why such an opinion arose. Namely, even though it is beyond any doubt that it was not the text which Copland translated, its affinity to the other two texts cannot be taken to be coincidental-they are clearly related.

Some additional evidence in support of the theories which postulate that the Laws of Oléron in their eMnE version were translated from either Le routier de la mer or a text similar to the one in Le grand coustumier comes in the shape of the perfect regularity of the divergences of the two MF texts and the eMnE rendition from the older AN copies. ${ }^{15}$ The texts are juxtaposed in Table 3 below. The two MF text are treated jointly. The data for the AN texts are taken from the copies contained in Liber Horn and Liber Memorandorum (cf. Section 2).

${ }^{15}$ As explained above, the AN texts are not included in the systematic comparison between the texts, as no direct line of descent can be traced between them, the MF versions of the Laws of Oléron and the eMnE translation. 
Table 3. Contents of the versions of the Laws of Oléron as contained in Liber Horn and Liber Memorandorum (AN), The Rutter of the Sea (eMnE), and Le routier de la mer and Le grand coustumier (MF)

\begin{tabular}{|c|c|c|c|}
\hline & $\begin{array}{c}\text { Liber Horn \& Liber Mem., } \\
\text { AN }\end{array}$ & $\begin{array}{c}\text { The Rutter of the Sea, } \\
\text { eMnE }\end{array}$ & $\begin{array}{c}\text { Le routier de la mer } \\
\text { and Le grand coustumier, } \\
\text { MF }\end{array}$ \\
\hline \multirow{27}{*}{ 范 } & 1 & 1 & 1 \\
\hline & 2 & 2 & 2 \\
\hline & 3 & 3 & 3 \\
\hline & 4 & 4 & 4 \\
\hline & 5 & 5 & 5 \\
\hline & 6 & 6 & 6 \\
\hline & 7 & 7 & 7 \\
\hline & 8 & 8 & 8 \\
\hline & 9 & 9 & 9 \\
\hline & 10 & 10 & 10 \\
\hline & 11 & 11 & 11 \\
\hline & 12 & 12 & 12 \\
\hline & 13 & 13 (the text is flawed) & 13 (the text is flawed) \\
\hline & 14 & 14 & 14 \\
\hline & 15 & 15 & 15 \\
\hline & 16 & 16 & 16 \\
\hline & 17 & 18 & 18 \\
\hline & 18 & 17 & 17 \\
\hline & 19 & 19 & 19 \\
\hline & 20 & 20 & 20 \\
\hline & 21 & 21 & 21 \\
\hline & 22 & 22 & 22 \\
\hline & 23 & 23 & 23 \\
\hline & 24 & - & - \\
\hline & - & 24 & 24 \\
\hline & - & 25 & 26 \\
\hline & - & 26 & 25 \\
\hline
\end{tabular}




\subsubsection{Comparison between Le routier de la mer and Le grand coustumier}

At this point, I would like to concentrate on the textual layer of the Laws of Oléron as contained in Le grand coustumier and Le routier de la mer, juxtaposing them with the eMnE rendition of the code in order to determine to which of the two the eMnE text is closer. It is, however, evident that any divergences that might be noted are minute and it is not my intention to provide an exhaustive list of them, or establish a stemma for the French text. It should also be noted that in order to determine the exact relationship between the 1502 and 1539 texts, one would need to analyse all points of divergence at different levels, e.g. orthographic, morphological or lexical, and use tools of statistical analysis in order to establish whether they indicate statistical significance of the findings. The analysis presented here is only intended to allow one to determine to which of the proposed source texts the eMnE rendition is closer and which of them most probably served as the basis for the translation. With this aim in mind, only the points of divergence resulting in the presence/absence of certain lexical or grammatical items in the two MF texts are listed below and juxtaposed with the eMnE rendition. The majority of them are only minor and invisible in the translation, being thus of no use in establishing the relationship between the eMnE and MF texts. However, in Table 4, I present all such places so that the reader can judge for themselves.

In total, there are 33 diverging points, with respect to the presence or absence of certain elements, between the two MF texts, all of them listed in Table 4 in the order of their appearance in the body of the code. Each row, with the exception of rows 21 and 26, illustrates a single divergence (set in bold). In row 21 there are two such points, i.e. the presence/absence of $s i$ 'if' and of a coordinated verb phrase. Similarly, two differences can be pointed to in row 26, where de 'of' is either present or absent and the numbers are either spelt out or presented with Roman numerals. I have tentatively grouped the divergences, trying to determine which reading in each case is closer to the eMnE rendition. The outcome of this is presented by means of shading of the eMnE text and one of the MF texts. In total then, in eight cases it is Le grand coustumier $(4,7,15,17$, $18,21,23$ and 26 (de)) which seems to have readings closer to the English translation, and in 13 Le routier de la mer $(5,6,8,10,13,16,19,22,24,25,26$ (numerals), 30 and 31). For the remaining 11 differences it is impossible to postulate anything in this respect. 
Table 4. Textual divergences between Le routier de la mer and Le grand coustumier

\begin{tabular}{|c|c|c|c|c|}
\hline & $\begin{array}{c}\text { Le routier de la mer, } \\
\text { MF }\end{array}$ & $\begin{array}{c}\text { Le grand coustumier, } \\
\text { MF }\end{array}$ & $\begin{array}{c}\text { The Rutter of the Sea, } \\
\text { eMnE }\end{array}$ & $\begin{array}{c}\text { Article } \\
\mathbf{n}^{\mathbf{0}}\end{array}$ \\
\hline 1 & $\begin{array}{l}7 \text { se frete a aller en pays } \\
\text { estrā }=\text { ge }\end{array}$ & $\begin{array}{l}\text { et frette a aller en pays } \\
\text { estrange }\end{array}$ & $\begin{array}{l}7 \text { is fraught to go } \overline{1} \text { to a } \\
\text { straūg coūtre }\end{array}$ & 1 \\
\hline 2 & Ce tēps nest mie bon & Ce temps nest pas bon & it is not good & 2 \\
\hline 3 & Et aussi silz ont tāt sauue & aussi silz ont tāt saulue & $\begin{array}{l}\text { yf they haue saued so } \\
\text { moche }\end{array}$ & 3 \\
\hline 4 & $\begin{array}{l}\text { la iustice du pays doit bien } \\
\text { garder }\end{array}$ & $\begin{array}{l}\text { la iustice du pays doibt biē } \\
\text { regarder }\end{array}$ & $\begin{array}{l}\text { the iustyce of the countre } \\
\text { ought well to regarde }\end{array}$ & 4 \\
\hline 5 & Et est tel le iugement & - & Suche is the iudgement & 5 \\
\hline 6 & $\begin{array}{l}\text { et puis font cōtēps et } \\
\text { meslees }\end{array}$ & $\begin{array}{l}\text { et puis sont contemp3 et } \\
\text { meslez }\end{array}$ & and make noyse and stryfe & 6 \\
\hline 7 & et si luy doit querir hostel & 7 luy doibt q̄rir hostel & 7 seke lodgynge for hym & 7 \\
\hline 8 & $\begin{array}{l}7 \text { aussi les aultres dērees q } \\
\text { encores } \mathbf{y} \text { sont }\end{array}$ & $\begin{array}{l}\text { et aussi les aultres denrees } \\
\text { qui encores sont }\end{array}$ & $\begin{array}{l}7 \text { the other goodes } y^{t} \text { is yet } \\
\text { in it }\end{array}$ & 8 \\
\hline 9 & $\begin{array}{l}\text { sil se deffēd comme bon } \\
\text { homme }\end{array}$ & $\begin{array}{l}\text { sil le deffend comme bon } \\
\text { homme }\end{array}$ & after his deseruyng & 8 \\
\hline 10 & cest le iugement & Ce en est le iugement & This is the iugement & 8 \\
\hline 11 & y fust tenable par loyaulte & il fut rēable par loyaulte & $\begin{array}{l}\text { it were reso=nable by } \\
\text { trouthe }\end{array}$ & 9 \\
\hline 12 & $\begin{array}{l}\text { Item vng maistre dune nef } \\
\text { vient a sauuete }\end{array}$ & $\begin{array}{l}\text { Item le maistre dune nef } \\
\text { vient a sauluete }\end{array}$ & $\begin{array}{l}\text { WHen a shyppe cometh } \\
\text { saufe }\end{array}$ & 10 \\
\hline 13 & $\begin{array}{l}\text { que les vins ne per }=\text { dirēt } \\
\text { par eulx ne par leur futaille } \\
\text { ne par le deffault }\end{array}$ & $\begin{array}{l}\text { que les vins ne perdirent par } \\
\text { eulx ne par leur futaille ne } \\
\text { leur deffault }\end{array}$ & $\begin{array}{l}\mathrm{y}^{\mathrm{t}} \text { the wyne was not lost by } \\
\text { theyr defaut nor by theyr } \\
\text { take=lyng }\end{array}$ & 11 \\
\hline 14 & $\begin{array}{l}\text { Et si nul desment le } \\
\text { mai=stre payera }\end{array}$ & $\begin{array}{l}\text { Et si nul desment le maistre } \\
\text { il payera }\end{array}$ & $\begin{array}{l}\text { And yf any belyeth the } \\
\text { mayster to paye }\end{array}$ & 12 \\
\hline 15 & $\begin{array}{l}\text { le marinier sen peult aller } \\
\text { suyure de la nef }\end{array}$ & $\begin{array}{l}\text { le marinier sen peult aller } \\
\text { suyure la nef }\end{array}$ & $\begin{array}{l}\text { the maryner may folowe the } \\
\text { shyp }\end{array}$ & 14 \\
\hline 16 & $\begin{array}{l}\text { le dommaige doit estre } \\
\text { parti et prisaige moytie par } \\
\text { moytie les deux nef3 }\end{array}$ & $\begin{array}{l}\text { le } \mathrm{do}=\text { maige doibt estre pti } \\
7 \text { prisaige moytie p moytie }\end{array}$ & $\begin{array}{l}\text { the losse ought to be } \\
\text { praysed } 7 \mathrm{de}=\text { uyded half to } \\
\text { half betwene y shyppes }\end{array}$ & 15 \\
\hline 17 & $\begin{array}{l}\text { et ya peu eaue } 7 \text { si asseche } \\
\text { lancre de la nef }\end{array}$ & $\begin{array}{l}7 \text { y a peu eaue } 7 \text { asseche } \\
\text { lācre de la nef }\end{array}$ & $\begin{array}{l}\text { at scant of water / and one } \\
\text { of the ankers lye to nere } \\
\text { another shyp }\end{array}$ & 16 \\
\hline 18 & $\begin{array}{l}\text { et le maistre de celle nef } \\
\text { doit dire }\end{array}$ & $\begin{array}{l}\text { le maistre dicelle nef doibt } \\
\text { dire }\end{array}$ & $\begin{array}{l}\text { the mayster of the sayd } \\
\text { shyppe ought to say }\end{array}$ & 16 \\
\hline
\end{tabular}




\begin{tabular}{|c|c|c|c|c|}
\hline 19 & $\begin{array}{l}7 \text { il3 ne veulent mie } \\
\text { lener }{ }^{16}\end{array}$ & 7 ilz ne veulēt & $\begin{array}{l}\text { And yf they wyll not } \\
\text { remeue it }\end{array}$ & 16 \\
\hline 20 & $\begin{array}{l}7 \text { puis que la nef est a la } \\
\text { terre au vin }\end{array}$ & $\begin{array}{l}\text { et puis que la nef est a terre } \\
\text { au vin }\end{array}$ & $\begin{array}{l}\text { And whan the ship is at the } \\
\text { shore }\end{array}$ & 17 \\
\hline 21 & $\begin{array}{l}\text { parquoy les mariniers se } \\
\text { puissent defēdre en la mer }\end{array}$ & $\begin{array}{l}\text { parquoy les mariniers si se } \\
\text { puissent def=fendre } 7 \\
\text { ayder a la mer }\end{array}$ & $\begin{array}{l}\text { wherby the maryners may } \\
\text { helpe them in the see }\end{array}$ & 18 \\
\hline 22 & $\begin{array}{l}\mathrm{au}=\text { cuns ya qui nont mie } \\
\text { lit ne arche }\end{array}$ & $\begin{array}{l}\text { aulcūs y a qui nōt mye } \\
\text { licine arche }\end{array}$ & $\begin{array}{l}\text { some there be that haue } \\
\text { neyther bed nor caben }\end{array}$ & 19 \\
\hline 23 & $\begin{array}{l}\text { de telle cuisine il au=ra en } \\
\text { la nef. deux des mariniers } \\
\text { en peuent porter }\end{array}$ & $\begin{array}{l}\text { de telle cuisine quil aura en } \\
\text { la nef deux des mariniers en } \\
\text { peuent porter }\end{array}$ & $\begin{array}{l}\text { Of suche meate as is in the } \\
\text { Shyppe / two of the } \\
\text { maryneres maye beare }\end{array}$ & 21 \\
\hline 24 & et tel pain comme il aura & 7 tel pain cōme il $\mathbf{y}$ aura & $\begin{array}{l}\text { and suche breade as they } \\
\text { haue }\end{array}$ & 21 \\
\hline 25 & $\begin{array}{l}\text { Ung maistre frete sa nef a } \\
\text { vng marchant }\end{array}$ & $\begin{array}{l}\text { Ung maistre frete la nef a } \\
\text { vng marchant }\end{array}$ & $\begin{array}{l}\text { IF a mayster freght his shyp } \\
\text { to a marchau(n)t }\end{array}$ & 22 \\
\hline 26 & $\begin{array}{l}\text { par lespace de viii. iours } \\
\text { ou de } \mathbf{x v} \text {. ou de plus }\end{array}$ & $\begin{array}{l}\text { par lespace de huyct iours / } \\
\text { ou de quinze / ou plus }\end{array}$ & $\begin{array}{l}\text { by the space of } \mathbf{x} \text { or } \mathbf{x v} \text {. } \\
\text { dayes or more }\end{array}$ & 22 \\
\hline 27 & $\begin{array}{l}\text { Le maistre doit ēuoyer } \\
\text { bien tost en son pays }\end{array}$ & $\begin{array}{l}\text { Le maistre doibt enuoyer } \\
\text { tost en son pays }\end{array}$ & $\begin{array}{l}\text { The maister ought for to } \\
\text { sende in haste îto his coūtre }\end{array}$ & 23 \\
\hline 28 & $\begin{array}{l}\text { il est tenu a ren=dre aux } \\
\text { marchans tous coust3 / } \\
\text { interest3 : ou dōmaiges } \\
\text { quil3 } \mathbf{y} \text { pourroient auoir }\end{array}$ & $\begin{array}{l}\text { il ē tenu a rēdre aux } \\
\text { marchās tous coustz / } \\
\text { interestz / ou dommaiges } \\
\text { quilz pourroiēt auoir }\end{array}$ & $\begin{array}{l}\text { he is bounde to redresse all } \\
\text { the domages of the } \\
\text { marchaūtes }\end{array}$ & 23 \\
\hline 29 & $\begin{array}{l}7 \text { en vendre pour querir } \\
\text { son estorment }\end{array}$ & $\begin{array}{l}\text { et vendre pour querir son } \\
\text { estorement }\end{array}$ & and make sale for his store & 23 \\
\hline 30 & $\begin{array}{l}\text { les vins que le maistre } \\
\text { aura prins doiuēt estre } \\
\text { affeures }\end{array}$ & $\begin{array}{l}\text { ce que le maistre aura prins } \\
\text { doibuēt estre affeurez }\end{array}$ & $\begin{array}{l}\text { the wyne that } \stackrel{\text { e }}{ } \text { may=ster } \\
\text { hath so takē ought to be } \\
\text { praysed }\end{array}$ & 23 \\
\hline 31 & $\begin{array}{l}\text { le tonneau defraude et } \\
\text { chiet et se pert } 7 \text { safonse } \\
\text { sur vng aultre sur lequel il } \\
\text { chiet et sont tous deux } \\
\text { perdus }\end{array}$ & $\begin{array}{l}\text { le tonneau defraude et chiet } \\
\text { et se pert } 7 \text { safonse sur vng } \\
\text { aultre sur le quel il chiet } 7 \\
\text { sont perdus }\end{array}$ & $\begin{array}{l}\text { it slyppeth and falleth vpon } \\
\text { another / and marreth them } \\
\text { bothe }\end{array}$ & 26 \\
\hline
\end{tabular}

However, as stated above, the majority of the divergences do not really introduce marked changes and are motivated by the structure of the text, which consists of long sentences with multiple subordination and coordination, resulting in the divergences in repetition of $s i$ 'if' and et 'and' but also of the preposition de 'of'. Usually the intention can be gathered from the context and thus-most

${ }^{16}$ This is a typographical mistake — most probably the text should read 'leuer'. 
probably - the English translator, similarly to translators nowadays, did not really feel compelled to imitate closely the use of conjunctions and preposition, especially that the two languages differ with respect to the verb-preposition combinations. Therefore, the convergence or divergence between the eMnE and MF could be coincidental in these places. If such instances are excluded from among the cases which can be considered to bring the $\mathrm{eMnE}$ rendition closer to one of the MF texts, there remain three places where the eMnE translation is closer to Le grand coustumier (4, 21 and 23), and 13 (listed above), where it resembles Le routier de la mer more. Therefore, on the whole, the text does seem to be closer to Le routier de la mer, especially that among the divergences involving the presence/absence or a difference in purely lexical items $(4,5,16$, $19,21,22,30,31$ ), as opposed to grammatical items, six among the eight bring the eMnE text closer in line with this earlier text and not with Le grand coustumier.

This is also supported by the publication dates. Only one of the texts - the one included in Le routier de la mer - was printed before the appearance of Robert Copland's 1528 rendition. Certainly, Twiss's (89) claim did not refer to this particular custumal as the actual source text for the translation but rather pointed to it as a copy close to the text from which the eMnE document was rendered. His claim has, thus, been fully corroborated. However, the textual evidence and the date of the publication both indicate that the text behind the eMnE translation was a copy of Le routier de la mer, which could have been based on a version of the laws current in Brittany at the time, as postulated by Twiss (89). It is also worth remembering that Le routier de la mer as a book, and not only the text of the Laws of Oléron it contains, corresponds perfectly to the eMnE Rutter of the Sea (Waters Rutters 170-175). The only exception is the final poem in the MF version which does not find an equivalent in the $\mathrm{eMnE}$ rendition.

It should also be noted that taking into account the indisputable similarities between the Laws of Oléron in le Roux's 1539 custumal and le Forestier's 1502 rutter, it seems likely that the latter, or a text similar to it, was the source of the text for le Roux's compilation. Since Le routier de la mer was printed in 1502 in Rouen, which is also the place where the custumal came into being, it is not surprising that le Roux managed to come into possession of a copy of the text. 


\section{CONCLUSION}

This paper has attempted to determine which of the supposed source textsLe routier de la mer (1502), Le grant routier (1520) and the text similar to the one copied later in Le grand coustumier (1539) - suggested with respect to the eMnE translation of the Laws of Oléron is the actual text underlying the rendition. Even though the versions of the code as presented in all three of the documents are undeniably similar, it was readily noticeable that there are only two actual possibilities when one juxtaposes the texts with the rendition, i.e. the source text was either a copy of Le routier de la mer (1502) or the version similar to that in Le grand coustumier (1539). Based on minor divergences between the two sources, the date of publication and the fact that the Laws of Oléron in their eMnE version are contained in a book called The Rutter of the Sea whose contents mirror the contents of the MF Le routier de la mer, it is suggested that it was a copy of this earlier text that probably served as the basis for the English translator. In other words, the analysis has shown that the translator of the eMnE text most probably used a version of Le routier de la mer as a basis, and that the remaining MF texts, i.e. the Laws of Oléron as contained in Le grand coustumier and Le grant routier, were possibly copied later from this or a similar French text. This evidence is a combination of the presence/absence of textual clauses (articles), dating, and contextual information.

\section{BIBLIOGRAPHY}

\section{SOURCES}

Cest le routtier. 1522. Bibliothèque nationale de France. Département des manuscrits, Français 1748.

Le grand costumier 1539 = Rouillé, Guillaume le, Andreas Alerensis, and Johannes Andreae, eds Le grand coustumier du pays et duche de Normendie / tres utile (et) profitable a tous practiciens [...]. Rouen, Nicolas Le Roux, 1539. Bibliothèque nationale de France, département Réserve des livres rares, RES-F-627.

Le grant routier $1525=$ Garcie, Pierre. Le grant routier [et] pilotage [et] enseigneme[n]t [...]. Rouen, Jehan Burges le ieune, 1525. Bibliothèque nationale de France, département Réserve des livres rares, SMITH LESOUEF R-198.

Le grant routier $1531=$ Garcie, Pierre. Le grant routier [et] pilotage [et] enseigneme [n]t [...]. Rouen, Jehan Burges, 1531. Bibliothèque nationale de France, département Arsenal, 4-S-3426.

Le grant routier 1531 = Garcie, Pierre. Le grant routier [et] pilotage [et] enseigneme[n]t [...]. Rouen, Jehan Burges le ieune, 1531. Bibliothèque nationale de France, département Réserve des livres rares, RESP-V-128.

Le grant routtier $1520=$ Garcie, Pierre. Le Grant routtier et pillo=tage et enseignement [...]. Poitiers, Enguilbert de Marnef, 1520. Bibliothèque Pierre-Moinot in Niort, RES-161E. 
Le routier de la mer jusques au fleuve de Jourdain. Rouen, Jacques le Forestier, [1502-1509]. Bibliothèque nationale de France, département Réserve des livres rares, Res-Z-2747.

Liber Horn ca. 1315. London Metropolitan Archives. COL/CS/01/002.

Liber Memorandorum ca. 1298/1314. London Metropolitan Archives. COL/CS/01/003.

Rutter of the Sea 1528 = Garcie, Pierre, and Robert Copland. [The Rutter of the Sea]. London, Robert Copland for Richard Bankes, 1528. British Library. Harley 5919.

Rutter of the Sea 1536 = Garcie, Pierre, and Robert Copland. The Rutter of the See [...]. London, Thomas Petyt, 1536. Lincoln's Inn Library.

Rutter of the Sea 1557 = Garcie, Pierre, and Robert Copland. The Rutter of the See [...]. London, Iohn Waley, [1557]. Beinecke Rare Book and Manuscript Library, Yale University Library. Taylor 87.

Rutter of the Sea 1560? = Garcie, Pierre, and Robert Copland. The Rutter of the See [...]. London, [Thomas Colwell], 1560? British Library. General Reference Collection C.21.a.51.

Rutter of the Sea. 1567? = Garcie, Pierre, and Robert Copland. The Rutter of the Sea [...]. London, William Copland, 1567? British Library. General Reference Collection C.21.a.48.

Rutter of the Sea. 1573? = Garcie, Pierre, and Robert Copland. The Rutter of the Sea [...]. London, Iohn Awdeley for Antony Kytson, 1573? British Library. General Reference Collection C.21.a.21.

\section{LITERATURE}

Amhydro. "Une histoire de l'hydrographie française", www.amhydro.org/histoire-hydrographie. Accessed 8 Sept. 2019.

Blayney, Peter W. M. The Stationers' Company and the Printers of London, 1501-1557, vols. 1 and 2. Cambridge University Press, 2013.

Bochaca, Michel, and Laurence Moal, eds. Le Grand Routier de Pierre Garcie dit Ferrande. Instructions pour naviguer sur les mers du Ponant à la fin $d u$ Moyen Âge. Presses Universitaires de Rennes, 2019.

Department of Vendée. "Le premier océanographe de l'histoire: Pierre Garcie-Ferrande, père de la cartographie marine", www.vendee.fr/Territoire-et-environnement/Environnement/Un-patrimoinemaritime-bien-vivant/Portraits-Nau-l-olonnois-et-Pierre-Garcie-Ferrande. Accessed 1 Oct. 2019.

Dictionary of Nautical Words and Terms. 8000 Definitions in Navigation, Seamanship, Rigging, Meteorology, Astronomy, Naval Architecture, Average, Ship Economics, Hydrography, Cargo Stowage, Marine Engineering, Ice Terminology, Buoyage, Yachting, etc. Ed. by Cyril Layton Walter Thomas, Peter Clissold, and A.G.W. Miller. 4th ed. Brown, Son and Ferguson, Ltd., Nautical Publishers, 1994.

Dictionnaire des auteurs anglais. Auteurs actifs dans les champs de l'histoire et de la politique en Angleterre de 1300 à 1600, lamop-intranet.univ-paris1.fr/auteurs_anglais/?i=presentation. Accessed 12 Sept. 2019.

Englebert's edition $=$ Garcie, Pierre. Le grant routtier et pillotage de la mer [...]. Poitiers, Enguilbert de Marnef, 1520. Ed. by Annick Englebert, www.diachronie.be/textes hlf/1520-garcie/83.html. Accessed 10 Sept. 2019.

English Short Title Catalogue, estc.bl.uk. Accessed 10 Sept. 2019.

Frankot, Edda. "Medieval Maritime Law from Oléron to Wisby: Jurisdictions in the Law of the Sea." Communities in European History: Representations, Jurisdictions, Conflicts, ed. by Juan Pan-Montojo, and Frederik Pedersen, Pisa University Press, 2007, pp. 151-172. 
Fumerton, Patricia. Unsettled: The Culture of Mobility and the Working Poor in Early Modern England. The University of Chicago Press, 2006.

Lis, Kinga. "On the Earliest English Translation of the Laws of Oléron and its Editions." Studia Anglica Posnaniensia, vol. 55, no.1, 2020, pp. 79-118.

Maisonneuve, Bernard de. Pierre Garcie dit Ferrande. Le Routier de la mer - v. 1490 - 1502 - 1520. CRHIP, 2015.

Pardessus, Jean-Marie, ed. Collection de lois maritimes antérieures au XVIII siècle, dédié au Roi, vol. 1. Paris, 1828.

Senior, William. "The Rutter of the Sea." The Mariner's Mirror, vol. 6, no. 8, 1920, pp. 243-246.

Sheppard, Leslie A. "The Rutter of the Sea." The British Museum Quarterly, vol. 11, no. 1, 1936, pp. 18-19.

Studer, Paul, ed. The Oak Book of Southampton of c. A.D. 1300. Transcribed and Edited from the Unique MS. in the Audit House, with Translation, Introduction, Notes, etc. Vol. 2, Cox and Sharland, 1911.

Trivellato, Francesca. "'Usages and Customs of the Sea'. Etienne Cleirac and the Making of Maritime Law in Seventeenth-century France." Tijdschrift voor Rechtsgeschiedenis/Revue d'Histoire du Droit/The Legal History Review, vol. 84, nos. 1-2, 2016, pp. 193-224.

Twiss, Travers, ed. The Black Book of the Admiralty, with an Appendix. Vol. 1. London, Longman and Co., and Trübner and Co., 1871.

Waters, David Watkin. The Art of Navigation in England in Elizabethan and Early Stuart Times. Hollis and Carter, 1958.

Waters, David Watkin. The Rutters of the Sea. The Sailing Directions of Pierre Garcie. A Study of the First English and French Printed Sailing Directions. With Facsimile Reproductions. Yale University Press, 1967.

\section{BEHIND THE EARLY MODERN ENGLISH TRANSLATION OF THE LAWS OF OLERON: DETERMINING THE UNDERLYING FRENCH TEXT}

\section{S u m m a ry}

The objective of this paper is to analyse the sixteenth-century French texts which might lie behind an Early Modern English translation of a sea-code known as the Laws of Oléron, in an attempt to determine which of them served as the actual basis for the rendition. The original code has been dated back to the thirteenth century, with the earliest extant copies coming from the fourteenth century, at which point it was already known and used in England. It was not, however, before the sixteenth century that a translation was commissioned and appeared in a book called The Rutter of the Sea. The publication in question went through multiple editions and the views concerning the French text that served as the basis for the rendition diverge greatly. This paper analyses the various proposed theories and juxtaposes the actual French texts with each other and the Early Modern English translation.

Key words: Laws of Oléron; Pierre Garcie dit Ferrande; Robert Copland; Rutter of the Sea; Thomas Petyt. 


\section{WCZESNE NOWOANGIELSKIE TŁUMACZENIE PRAW Z OLÉRONU: W POSZUKIWANIU FRANCUSKIEGO TEKSTU ŹRÓDŁOWEGO}

\section{Streszczenie}

Celem artykułu jest analiza XVI-wiecznych tekstów francuskich, które mogły być tekstami źródłowymi dla wczesnego nowoangielskiego tłumaczenia kodeksu morskiego znanego jako Prawa z Oléronu. Badanie ma pozwolić na ustalenie, który z nich stał się podstawą thumaczenia. Sam kodeks morski powstał w XIII wieku, a jego najstarsze zachowane kopie pochodzą z XIV wieku, kiedy był już znany i wykorzystywany w Anglii. Jednakże dopiero w XVI wieku zlecono jego thumaczenie na język angielski i został wydany w książce The Rutter of the Sea. Publikacja miała kilka edycji, a poglądy dotyczące tekstu francuskiego, który był jej źródłem, znacząco od siebie odbiegają. Artykuł analizuje różne teorie dotyczące tekstu źródłowego i zestawia ze sobą proponowane jako źródła teksty francuskie, a także porównuje je z tłumaczeniem na wczesny nowoangielski.

Słowa kluczowe: Prawa z Oléronu; Pierre Garcie dit Ferrande; Robert Copland; Rutter of the Sea; Thomas Petyt. 